\title{
WHY THERE IS AN URGENT NEED FOR SUSTAINABLE DEVELOPMENT IN AFGHANISTAN?
}

\author{
Ahmad Ehsan KAKAR \\ İstanbul Aydın University, Turkey \\ ehsankakar2010@gmail.com \\ https://orcid.org/0000-0003-1127-5483 \\ Assist. Prof. Dr. Hasan Volkan ORAL \\ İstanbul Aydın University, Turkey \\ volkanoral@aydin.edu.tr \\ https://orcid.org/0000-0002-5743-1931 \\ Prof. Dr. Hasan SAYGIN \\ İstanbul Aydın University, Turkey \\ hasansaygin@aydin.edu.tr \\ https://orcid.org/0000-0003-2479-7635
}

\begin{abstract}
Afghanistan is a country in South-Central Asia. Afghanistan is bordered by Pakistan in the South and East; Iran in the West; Turkmenistan, Uzbekistan and Tajikistan in the North; and in the Far Northeast, China is a neighboring country. Due to its historical and economic importance, Afghanistan has suffered from wars, political and social turmoil, and this problem remains unresolved. The problems of Afghanistan must be solved urgently. In this study, the problems seen in Afghanistan have examined and concrete solutions have been proposed regarding the sustainable development that can be implemented. However, implementing Sustainable Development is not as easy as it might be thought. There are some practical challenges and, as a first step, these challenges need to be resolved through informed discussions and information sharing on existing platforms. The aim of this study is to investigate the applicability of Sustainable Development in Afghanistan.
\end{abstract}

Keywords: Sustainable Development, Social Welfare, Poverty, Sustainable Development Goals, Afghanistan 


\section{AFGANISTAN'DA NIÇİN SÜRDÜRÜLEBİLİR BİR KALKINMAYA ACIL İHTIYAÇ VAR?}

\section{ÖZ}

Afganistan, Güney-Orta Asya'da bulunan bir ülkedir. Afganistan, Güney ve Doğu'da Pakistan tarafından sınırlanmıştır; Batı'da İran; Kuzey'de Türkmenistan, Özbekistan ve Tacikistan; ve Uzak Kuzeydoğu'da, Çin komşu ülke olarak yer almaktadır. Tarihsel ve ekonomik önemi nedeniyle Afghanistan, savaşlardan, siyasi ve sosyal kargaşadan acı çekmiştir ve halen bu sorun çözülememiş̧ir. Afganistan'ın sorunlarının acilen çözülmesi gerekmektedir. Bu çalışmada, Afganistan'da görülen sorunlar incelenmiş ve uygulanabilecek Sürdürülebilir Kalkınma ile ilgili somut ve somut çözümler önerilmiştir. Ancak, Sürdürülebilir Kalkınma uygulamalarını gerçekleştirmek düşünüldüğü kadar kolay değildir. Uygulamaya yönelik bazı zorluklar vardır ve ilk adım olarak, bu zorlukların mevcut platformlarda bilinçli tartışmalar ve bilgi paylaşımı ile çözülmesi gerekmektedir. Bu çalışmanın amacı Afganistan'daki Sürdürülebilir Kalkınma konusunun uygulanabilirliğini araştırmaktır.

Anahtar Kelimeler: Sürdürülebilir Kalkınma, Toplumsal Refah, Fakirlik, Sürdürülebilir Kalkınma Hedefleri, Afganistan

\section{INTRODUCTION}

The aim of this article is to offer solid solutions which can be considered under Sustainable Development in Afghanistan. It is very difficult to make the definition of Sustainable Development. However, the sustainable development outlined by the United Nations covers the principle of leaving today's natural resources without consuming and polluting the future of tomorrow. Sustainable development has three main pillars: economic, social and environmental.

According to Harris (2003) in the widespread debate and use of the idea since then there has been a growing recognition of three crucial aspects of sustainable development such as social, economic and environmental.Asystem of economically sustainable must be able to produce services and goods on a permanent basis, to sustain manageable levels of government and exterior debt, and to avoid extreme sectoral imbalances which hurt industrial or agricultural production. A system of environmentally sustainable must preserve a steady source base, avoiding over-exploitation of renewable sources systems or environmental sink purposes, and reducing nonrenewable sources only to the point that investment is made in sufficient alternates. This contains preservation of biodiversity, atmospheric constancy, and other ecosystem purposes not ordinarily categorized as economic sources. A system of socially sustainable must attain fairness in spreading and 
opportunity, sufficient provision of social services including gender equity, health and education, and political responsibility and participation (Harris,2003).

Harris (2003) also stated that three elements of sustainability present several potential difficulties to the original, simple definition of economic growth. The objectives stated or implied are multidimensional, raising the concern of how to judge triumph or failure and how to balance aims. For instance, what if provision of sufficient water and food supplies seems to oblige alterations in land use that will decline biodiversity? What if non-polluting energy resources are more expensive, thus growing the burden on the poor, for whom they represent a larger amount of daily spending? Which objective will take precedence? The General Assembly (2015) adopted the 2030 Agenda for Sustainable Development that contains 17 Sustainable Development Goals (SDGs). Building on the belief of "leaving no one behind", the new Agenda highlights a holistic method to attaining sustainable development for all. The Agenda of 2030 for Sustainable Development, approved by wholly United Nations Member States in 2015, offers a shared blueprint for prosperity and peace for people and the planet, present and into the future. At its heart are the 17 Sustainable Development Goals (SDGs), which are a crucial call for action by wholly countries - developing and developed - in a worldwide corporation. They identify that termination of poverty and other deficiencies must go hand-in- hand with policies that advance education and health, spur economic development and decrease inequality- all while tackling weather change and working to reserve our oceans and forests.

\section{Geographical Information About Afghanistan}

Afghanistan, is a multiethnic country located in the heart of south-central Asia. The country is locating along significant trade roads joining southern and eastern Asia to Europe and the Middle East, Afghanistan has long been a prize sought by empire builders, and for millennia great armies have tried to subdue it, leaving traces of their struggles in great monuments now fallen to collapse. The country's forbidding landscape of mountains and deserts has laid a lot of imperial motivations to rest, as has the tireless resistance of its fiercely independent peoples - so independent that the country has failed to coalesce into a nation but has instead long endured as a patchwork of contending ethnic factions and ever-shifting alliances. The backbone of Afghanistan's economy is Agricultural production. The country is famous for producing some of the best grapes, melons, pomegranates, apricots and some more fresh and dry fruits. It is also famous as the world's largest producer of opium. Sources indicate that as much as $11 \%$ or more of the nation's economy is derived from the sale and cultivation of opium (URL1). 


\section{BACKGROUND}

The main problems that are seen in Afghanistan are Civil War, Poverty, Inequality of Women, Environmental Problems:

\section{AFGHAN CIVIL WAR}

According to Human Rights Watch (2017) fighting between Afghan government and Taliban forces intensified through 2017, causing high numbers of civilian casualties. Principally in Nangarhar province, government forces also battled the Islamic State of Khorason Province (ISKP), the Afghan branch of the extremist group Islamic State (also known as ISIS). Several particularly deadly suicide attacks in urban areas, some claimed by ISKP, killed and wounded more than 2,000 people across the country. A growing number of these attacks targeted Afghanistan's Shia Hazara minority. Civilian casualties caused by government forces during ground fighting declined; however, US forces expanded their use of airstrikes, including drones, in military operations, causing increased civilian casualties.

\section{POVERTY}

Afghanistan faces numerous difficulties, containing prevalent poverty. Despite a powerful governmental obligation to address poverty and 15 years of economic growth and global financial support, poverty decrease results are limited and growth profits have not attained most of the population. To grow a more efficient poverty, decrease policy and priorities interferences, it is essential to recognize who the poorest social collections are and in what sizes of wellbeing they are deprived (Trani et al., 2016).

\section{INEQUITY OF WOMEN}

UNICEF (2017) declares that girls and women in Afghanistan continue to face extensive discrimination and human rights misuses. Afghanistan positions among the least favorable on the Gender Inequality Index and the literacy rate for women is among the lowest in the world. Cruelty against girls and women is widespread and the most don't go to school. Yet women make up $50 \%$ population of this country. Progress for them means progress for wholly, and it is very important for the future of the country and the constancy of the nation. Sex equality means that men and women, and boys and girls, enjoy the same rights, protections, opportunities and resources. Showed by the UNICEF Gender Action Plan, this organization in Afghanistan is committed to sex equality at the core of our mission to understand the rights of every child, specially the most disadvantaged, and in our struggles to donate to the SDGs. As giving an example for that, girls' learning assists to avoid child marriage and offers a protective space. The high occurrence of anemia among teenage girls influences their capability to survive 
childbirth, particularly when it is coupled with high rates of early marriage. The ability of teenage girls to safely manage their monthly menstrual series in privacy and with dignity is essential to their health, psychosocial well-being and mobility (UNICEF, 2017).

Notwithstanding enormous developments since the end of the Taliban occupy, women till now face extensive discrimination and human rights misuses. Women are mostly restricted to low-paid, unregulated employment, annoyance is extensive, political contribution and educational chances are restricted, and women face many difficulties to obtaining reasonable treatment from the justice system (UNDP). UNDP works with the Ministry of Women's Affairs and other government bodies to implement key obligations on sex equality, gender mainstreaming and women's rights. This contains capacity building for government and other staff and assistance in observing progress against gender benchmarks.

\section{ENVIRONMENTAL PROBLEMS}

Environmental concerns in Afghanistan precede the political turmoil of the past few periods. Wetlands and forests have been evacuated by centuries of farming and grazing, practices which have only increased with modern population growth. Economic issues and environmental conservation in Afghanistan are not at odds; with $80 \%$ of the population dependent on farming or herding, the welfare of the environment is very important to the economic welfare of the people. The World Health Organization in 2007, released a report ranking Afghanistan as the lowest among non-African nations in deaths from environmental dangers.

Nowadays, commonly as a result decade of political conflict and chaos, this country is in a state of severe environmental disaster. Although some developments and regulatory improvements have been made after the fall of the Taliban for example the creation of the National Environmental Agency (NEPA) in 2005, and the passing of Afghanistan's first Environmental Law in 2007, many more requires to be done. Air and water pollution, soil degradation, deforestation at an alarming rate, desertification, overgrazing, and over population in its already fragile urban areas are the main environmental concerns nowadays for Afghanistan. Also there are many limited, unequally distributed, and poorly managed natural fresh water resources in this country.

United Nation Environment has taken an active character in setting the environmental fundamentals for SD in Afghanistan since 2002. Decades of violence and war, joined with earthquakes and drought, have had disturbing influences on the people of Afghanistan, and also on its natural environment, once 
pristine and rich in biological diversity. UN Environment's arrangement started with a major post-conflict environmental assessment, conducted in conjunction with the Government of Afghanistan and Afghan environmental specialists. Published in 2003, the evaluation underlined significant and extensive land and resource degradation, containing desiccation of wetlands, lowered water tables, erosion, loss of wildlife and extensive loss of vegetative cover. This led to a demand from the Afghan Government for practical assistance to establish a national environmental organization. UN Environment's assistance has since extended to emphasis on upgrading formations of governance and on addressing crucial urban environmental and natural resource management concerns. UN Environment is committed to advancing the improvements made in SD in Afghanistan over the past periods. A concerted method, leveraging the practical and policy direction of organizations like National Environmental Protection Agency (NEPA), and of implementing organizations like the Ministry of Agriculture, Irrigation and Livestock, is vital to continuing successes.

\section{RESULTS}

After evaluating the problems raised in this study, the realization of Sustainable Development in Afghanistan needs to be implemented as soon as possible and without delay. On the other hand, the following implementations should be implemented as soon as possible in order to realize this development plan.

1. The Afghan Government needs to develop a strategy on Sustainable Development, taking into account the reports issued by international institutions.

2. Workshops and symposia should be held first in the region and then throughout the country with the participation of academics from all parts of society in Afghanistan to solve the problems.

3. Local programs should be implemented where women's rights are protected and girls are encouraged to study. Those who do not comply with this program should be severely punished.

4. Financial aid sent from abroad to the country needs to be managed and distributed from a single source and centrally to the regions in need.

5. Qualified infrastructure needs to be established in order to eliminate environmental problems, but the implementation of this article depends on the ongoing political chaos and the complete eradication of civil war in the country. 


\section{REFERENCES}

Anand, Sudhir \& Amartya K. Sen. (1996). Sustainable Human Development: Concepts and Priorities.

Ghobar, Mir Gholam Mohammad (1999), Afghanistan in the Course of History. Hashmat K. Gobar.

Harris, J. M., (2003) Sustainability and Sustainable Development, International Society for Ecological Economics

Human Rights Watch, (2017), Afghanistan Events of 2017.

Ministry of Economy, (2017), SDGs Progress Report, Afghanistan.

Reed ed. (1996), Structural Adjustment, the Environment and Sustainable Development. London: Earthscan.

Trani JF et al., (2016) Multidimensional poverty in Afghanistan: who are the poorest of the poor?, Oxford Development Studies, 44:2, 220245, DOI: $10.1080 / 13600818.2016 .1160042$

UNICEF (2017) Afghanistan Report, unicef.org.

URL1: Britannica.com (2019) https://www.britannica.com/place/Afghanistan 